M.Y. Khan

Tiwari, C.

Murari Lal

N. Haque

\section{Nutritional assessment of wheat straw, untreated or urea treated using respiration calorimetry technique}

Respirationstechnik zur Bewertung von Weizenstroh

Wheat straw is one of the most widely used feeds for ruminant livestock in India. It is high in ligno-cellulosic content but is poor in protein ( 2 - 4 \% C.P.). Nutritional evaluation of wheat straw, untreated or urea treated, was done by conducting two separate experiments using respiration calorimetry technique.

Experiment I was conducted on 8 male adult buffaloes, weighing about $420 \mathrm{~kg}$ and divided into two groups of 4 each. The animals were fed similar level of protein but 100 or 80 percent of energy requirements from rations consisting of decorticated de-oiled groundnut cake, wheat straw, common salt, mineral mixture, and a vitamin A supplement. A switch over design was followed to have two different levels of feeding of wheat straw and similar level of GNC for each animal. Metabolism trials followed by respiration calorimetry studies in an open circuit respiration chamber were conducted. The digestible and metabolisable energy contents of wheat straw, as determined by difference method, were $1.75 \pm$ 0.77 and $1.42 \pm 0.04 \mathrm{Mcal} / \mathrm{kg} \mathrm{DM}(7.3$ and $5.9 \mathrm{MJ})$, respectively. Each $\mathrm{kg}$ of TDN contained $4.34 \pm 0.03$ and $3.52 \pm 0.04$ Mcal DE and ME (18.2 and $14.7 \mathrm{MJ}$ ), respectively. In experiment 2 the energy values of urea ammoniated wheat straw (UAS) (4\% urea, 28 days ensiling) and $1.5 \% \mathrm{w} / \mathrm{w}$ urea supplemented wheat straw (USS) were determined on 4 adult male buffaloes. Metabolism trials and chamber studies were conducted on ad libitum feeding of each ration in two different periods. The DE and ME content of UAS and USS were $2.34 \pm$ 0.07 and $2.15 \pm 0.06$ and $2.05 \pm 0.05$ and $1.75 \pm 0.03$ $\mathrm{Mcal} / \mathrm{kg} \mathrm{DM}$, (9.8 and $9.0 ; 8.6$ and $7.3 \mathrm{MJ} / \mathrm{kg}$ ), respectively. Loss of faecal energy as percent of GE intake was higher from USS than UAS but there was no significant difference between the two in urinary and methane energy losses. 